\title{
AN ORGANOPHOSPHATE INSECTICIDE METHYL PARATHION $(O-O$ - DIMETHYL $O$-4-NITROPHENYL PHOSPHOROTHIOATE) INDUCES CYTOTOXIC DAMAGE AND TUBULAR ATROPHY IN THE TESTIS DESPITE ELEVATED TESTOSTERONE LEVEL IN THE RAT
}

\author{
Kilarkaje NARAYANA ${ }^{1}$, Narayan PRASHANTHI ${ }^{2}$, Arunkumar NAYANATARA ${ }^{3}$, \\ Laxminarayana K. BAIRY ${ }^{4}$ and Urban J. A. D'SOUZA ${ }^{5}$ \\ ${ }^{1}$ Department of Anatomy, Faculty of Medicine, HSC, Kuwait University, \\ P.O. Box No. 24923, Safat 13110, Kuwait \\ Departments of Anatomy ${ }^{2}$ and Physiology ${ }^{3}$, Center for Basic Sciences, Kasturba Medical College, \\ Bejai, Mangalore-575004, Karnataka, India \\ ${ }^{4}$ Department of Pharmacology, Kasturba Medical College, \\ Madhav Nagar, Manipal, Karnataka, India \\ ${ }^{5}$ School of Medicine, University Malaysia Sabah, 88999, Kota Kinabalu, Sabah. Malaysia
}

(Received February 27, 2006; Accepted April 5, 2006)

\begin{abstract}
Methyl parathion (MP) is an organophosphate pesticide used in agriculture, although quite often illegally used indoors to contain insects. The present study was planned to investigate the effects of MP on rat testis. Adult male Wistar rats (13-14 weeks) were treated with MP as follows. Experiment 1-0, 1.75, 3.5 or $7 \mathrm{mg} / \mathrm{kg}$ i.p. for 5 days and sacrificed on Day 14; experiment 2 and 3- 0, 0.5, or $1 \mathrm{mg} / \mathrm{kg}$ i.p. for 12 days, and sacrificed on Days 130 and 77, respectively; experiment 4- 0, 0.75, or 1.5 $\mathrm{mg} / \mathrm{kg}$ i.p. for 25 days, and sacrificed on Day 17; experiment $5-0$ or $3.5 \mathrm{mg} / \mathrm{kg}$ po for 25 days, and sacrificed on Day 17, after the last exposure. MP decreased the body weight and the testis weight in experiments 4 and $5(\mathrm{p}<0.05-0.001)$ due to decreased food intake and tubular atrophy respectively. MP increased the intra-testicular testosterone level and decreased the LH level in experiments 4 and 5. The seminiferous epithelium showed sloughing of germ cells, vacuoles, focal necrosis, and formation of multinucleated giant cells, cellular degeneration (nuclear pyknosis, halo appearance and shrinkage of nuclei) and tubular atrophy, especially in experiment 4 . The degree of testicular damage was higher in experiment $4>5>1>3>2$ indicating more effect of prolonged i.p. treatment. Homogenization-resistant spermatid count was decreased in experiments 1, 4 and 5, and MP also decreased the tubular diameter, and epithelial height $(\mathrm{p}<0.05-0.001)$. Incidences of stage XIV tubules, number of meiotic figures and elongating spermatids were also decreased, whereas the incidence of tubules showing epithelial sloughing increased $(\mathrm{p}<0.05-$ 0.001). We conclude that MP is a reproductive toxicant in male rats which causes significant testicular damage in the testis.
\end{abstract}

KEY WORDS: Endocrine disruptors, Anti-estrogen, Gonadotoxicity, Pesticides, Testicular degeneration

\section{INTRODUCTION}

Now it is well known that exposure to environmental chemicals such as pesticides results in cancers or reduced reproductive functions in humans and animals (Sharpe and Skakkebaek, 1993; Toppari et al.,
1996; Wesseling et al., 1999; Sharpe and Irvine, 2004). A major part of these environmental toxicants includes pesticides to which humans may be exposed during farm- related activities, or during illegal domestic use to contain insects, or due to contamination of the food chain (Makita et al., 2005). There are several incidents

Correspondence: Kilarkaje NARAYANA (E-mail: narayana68@yahoo.com) 
of illegal domestic spraying of pesticides, which are licensed only for outdoor use. One such episode was a tragic event of illegal domestic spraying of MP-a so called 'methyl parathion story' - that happened in at least nine states, including Mississippi and Ohio, in the United States in the 1990s (Rubin et al., 2002; Zeitz et al., 2002; Ruckart et al., 2004).

Methyl parathion (MP), nicknamed as 'cotton poison,' is an organophosphate pesticide licensed only for outdoor use in almost all countries including the United States. More often than not, however, it is illegally used indoors to control insects such as cockroaches due to its effectiveness, inexpensiveness and long-time persistence, thus keeping insects out for a long time (Zeitz et al., 2002). Thus, it is one of the numerous pesticides present in traces in the human blood when evaluated in a cross-section sample of the United States population (Barr et al., 2005). Besides, it is also present in traces in rivers and seawater, which might form yet another route of exposure to MP in both humans and animals (IPCS, 1993; Aleem and Malik, 2005). MP is an inhibitor of enzyme acetylcholinesterase, a biochemical event that results in the accumulation of endogenous acetylcholine at the nerve endings (Tang et al., 2003; Ma et al., 2003). Although effects of MP on the female reproductive system have been considerably investigated, very little research has been carried out on the male reproductive system. MP was found to be teratogenic in chicken embryos and rodents in which it induced fetal mortality and skeletal malformations such as cleft palate and cervical ribs (Jelinek et al., 1985; Vernagy and Deli, 1985; IPCS, 1993; Kumar and Devi, 1992). Daily intra-peritoneal injections of 1 or $1.5 \mathrm{mg} / \mathrm{kg}$ MP to pregnant rats during gestation Days 6-19 induced a decrease in fetal and maternal protein synthesis in a dose-dependent manner (Gupta et al., 1984) and also decreased the postnatal cholinesterase levels (Gupta et al., 1985). At dose-levels of $2.5-5 \mathrm{mg} / \mathrm{kg}$, MP decreased compensatory ovary weight gain and incidences of healthy follicles in hemi-castrated rats (Dhondup and Kaliwal, 1997), and also affected the estrous cycle (Asmathbanu and Kaliwal, 1997). On the other hand, MP is known to induce sperm shape abnormalities and to decrease the sperm count in rodents, possibly by a mechanism related to reduced ascorbic acid level in the testis (Mathew et al., 1992; Narayana et al., 2005a). In white-throated munias (Lonchura malabarica), MP induced testicular damage, an effect that should have been mediated via decreased acetylcholinesterase activities (Maitra and Sarkar, 1996). However, there are no or very few studies investigating the testicular effects of MP after short and long-term treatments. The present study was planned to investigate the effects of MP on the rat testis.

\section{MATERIALS AND METHODS}

\begin{abstract}
Animals
Adult male Wistar rats of 13-14 weeks old at the time of onset of treatments were used in the present study. The rats were procured from the Central Animal Breeding Center at our University. Animals were housed in polypropylene cages with paddy husk bedding at $28 \pm 2{ }^{\circ} \mathrm{C}$ temperature and $50 \pm 5 \%$ humidity. Animals were fed on laboratory chow and water $a d$ libitum. In the present study, 5 rats/group/particular dose/ sample time were used. Rats were anesthetized (Pentobarbitone sodium, $45 \mathrm{mg} / \mathrm{kg}$, i.p.) and then sacrificed by giving the terminal dose.
\end{abstract}

\section{MP and treatment schedule}

MP (Metacid 50; $o$ - $o$ - dimethyl $o$-4-nitrophenyl phosphorothioate) is manufactured and marketed by Bayer India Ltd., (Mumbai). It is an emulsifiable insecticide containing $50 \% \mathrm{w} / \mathrm{w}$ methyl parathion. The required amount of MP was measured before every treatment and suspended in water for injection, and treated either via i.p. or p.o. route (Mathew et al., 1992; Narayana et al., 2005a). The treatment schedule was as follows. Experiment 1- 0, 1.75, 3.5 and $7 \mathrm{mg} / \mathrm{kg}$, i.p. equivalent to $1 / 4,1 / 2$ and 1 times of $\mathrm{LD}_{50}$ respectively (IPCS, 1993) for 5 days and sacrificed on $14^{\text {th }}$ day; experiment 2- 0, 0.5 and $1 \mathrm{mg} / \mathrm{kg}$, i.p. for 12 days and sacrificed on $130^{\text {th }}$ day; experiment $3-0,0.5$, or $1 \mathrm{mg}$ / $\mathrm{kg}$, i.p. for 12 days and sacrificed on $77^{\text {th }}$ day; experiment 4- $0,0.75 \mathrm{mg} / \mathrm{kg}$ and $1.5 \mathrm{mg} / \mathrm{kg}$, i.p. for 25 days and sacrificed on $17^{\text {th }}$ day; and experiment 5- 0, 3.5 $\mathrm{mg} / \mathrm{kg}$, p.o. equivalent to $1 / 2$ of $\mathrm{LD}_{50}$ (IPCS, 1993) for 25 days and sacrificed on $17^{\text {th }}$ day, after the last exposure. Doses used in experiments 2-4 were smaller doses although higher than human exposure dose-levels. There are no clues in the literature on sampling time for the testis in MP treated rats. Therefore we undertook a screening study to observe the testis after MP exposure (doses used were similar to those used in experiment 1 , treated for 5 days), and noticed the changes in testicular structure on Day 14 after the last exposure (data not shown). No significant changes were observed before the end of the second week. We were not able to observe any structural or biochemical changes immediately after the $5^{\text {th }}$ treatment. Hence, the 
Testicular toxicity of methyl parathion.

earliest sample time selected was on the $14^{\text {th }}$ day after the last exposure. During this study, 3 animals died before completion of treatm ent due to toxicity, and we replaced them with new recruitment. We sacrificed the rats on $130^{\text {th }}$ and $77^{\text {th }}$ days in experiments 2 and 3 to evaluate the recovery phase of the effects. Experiment 4 was meant to evaluate the effects of moderately longterm i.p. treatment of small doses of 0.75 or $1.5 \mathrm{mg} / \mathrm{kg}$. Similarly, experiment 5 was planned to investigate the effects of moderately long-term p.o. exposure to a higher dose, $3.5 \mathrm{mg} / \mathrm{kg}$. In the latter experiment, 3 rats died during treatment and were replaced.

\section{Evaluation of MP toxicity \\ 1. Body weight and testis weight}

Before, during and after the treatments, each animal was weighed accurately to nearest gram. Animals were sacrificed and laparotomy was conducted to expose the reproductive system. The testis was removed, weighed and processed for light microscopical analysis (Culling et al., 1985).

\section{Hormone estimation in the testis \\ 1. Intra-testicular testosterone level}

The level of testosterone in the homogenate of the testis was estimated by Electrochemiluminescence Immunoassay- ECLIA in Roche Elecsys 1010 Immunoassay analyzer, Germany (Roche Diagnostics $\mathrm{GmbH}$ D-68298 Mannheim). This estimation was based on a competitive test principle using a monoclonal antibody specifically directed against testosterone. Endogenous testosterone released from the sample by 8-anilino-1naphthalene sulfonic acid and norgestrel competes with the added testosterone derivative labeled with ruthenium complex for the binding sites on the biotinylated antibody.

\section{Intra-testicular leutinizing hormone (LH) level}

This assay was also performed by Electrochemiluminiscence immunoassay (ECLIA) in Roche Elecsys 1010 immunoassay analyzer (Roche Diagnostics GmbH D-68298 Mannheim). The test was performed as per the procedures provided by the suppliers.

\section{Histopathological analysis of testis \\ 1. Qualitative changes}

$5 \mu \mathrm{m}$ thick sections from each testis were evaluated for MP-induced structural changes. Qualitative analysis of histopathological changes such as epithelial sloughing, appearance of abnormal cells, cellular changes and tubular atrophy were made (D'Souza and
Narayana, 2002; Narayana et al., 2005b).

\section{Quantitative changes}

In each animal, one hundred tubules were counted and tubules exhibiting epithelial exfoliation (sloughing) were documented. One hundred tubules per animal were screened and classified into degenerative and atrophic tubules. The degenerative tubules were the ones which showed disrupted cell association and degeneration. Tubules which showed very few or no germ cells but Sertoli cells were classified as atrophic tubules. This parameter was conducted only in experiment 4 , since the tubules showed extensive damage, due to which epithelial sloughing, and cytotoxic parameters (except spermatid count; vide infra) could not be analyzed.

\section{Morphometrical analysis of the testis}

One testis from each rat was examined for structural changes. In each testis, 5 transversely cut stage VII tubules were selected. The seminiferous tubular diameter (STD) was measured by using a stage micrometer calibrated with eyepiece micrometer. Two diameters of the tubule- one perpendicular to the other were measured and the average was taken for each animal. The seminiferous epithelial height (SE) was measured in 5 transversely cut stage VII tubules. Two measurements of the epithelium were taken and their average served as the SE (Narayana et al., 2005b). In each testis, 5 transversely cut stage VII tubules were selected. In each tubule, diameters of nuclei of spermatogonia, primary spermatocytes, and round spermatids were measured. The average was taken for each animal and the radius (r) was used to obtain the nuclear volume by using the formula $4 / 3 \pi r^{3}$.

\section{Cytotoxicity of MP on testis}

One testis of each rat was homogenized in $5 \mathrm{ml}$ phosphate buffered saline for the estimation of homogenization resistant spermatid count. An aliquot was taken from this suspension in a leukocyte hemocytometer up to mark 0.5 and then diluted with PBS up to mark 11. The suspension was mixed well and charged into a Neuabauer's counting chamber and the spermatids were counted as per the standard procedure (Vega et al., 1988; Narayana et al., 2002, 2005b). In each animal, 5 transversely cut stage XIV tubules were identified. The Sertoli cell nucleoli, meiotic figures, and elongating spermatids (step 14) were counted and expressed as per Sertoli cell nucleolus incidence. One hundred tubules were counted in each animal and per- 
centage incidence of stage XIV tubules was documented.

\section{Statistical analysis}

Data were represented as means \pm S.D. from 5 animals/group. The differences were compared for statistical significance by one way ANOVA followed by Bonferroni's post hoc test (Narayana et al., 2005a). However, the data from experiments 5 were analyzed by the Mann-Whitney ' $U$ ' test (Narayana et al., 2005a). In all cases the significance level was set at $\mathrm{p}<0.05$. Data analysis has been carried out by SPSS package version 10 (SPSS Inc. Head Quarters, 233 S. Waker Drive, $11^{\text {th }}$ Floor Chicago, Illinois, 60606). We have presented only those results, which were significantly different from the control and all negative data were ignored and not presented here.

\section{RESULTS}

\section{Body weight and testis weight}

MP decreased the body weight of rats in experiments 4 and 5 (Fig. 1a and b). There was no effect of MP on body weight of rats in experiments 1-3. The weight decrease in experiment 4 was significant at 1.5 $\mathrm{mg} / \mathrm{kg}$ on $4^{\text {th }}, 8^{\text {th }}$ and $12^{\text {th }}$ day; and at $0.75 \mathrm{mg} / \mathrm{kg}$ on $16^{\text {th }}$ and $24^{\text {th }}$ day; and at both dose-levels on $20^{\text {th }}, 28^{\text {th }}$ and $32^{\text {nd }}$ day $(\mathrm{p}<0.05-0.001)$. The weight decrease did not follow any particular dose-response. Instead, at doselevel of $0.75 \mathrm{mg} / \mathrm{kg}$; the effect was more on the $16^{\text {th }}$, $20^{\text {th }}, 24^{\text {th }}$ and $28^{\text {th }}$ days (Fig. 1a). Similarly, significant weight decrease was observed in experiment 5 at 3.5 $\mathrm{mg} / \mathrm{kg}$ on the $13^{\text {th }}$ day through the $38^{\text {th }}$ day $(\mathrm{p}<0.01$; Fig. 1b). Like body weight, the testis weight was also decreased only in experiments 4 and 5; however, the effect was more in experiment 5 after p.o. exposure to $3.5 \mathrm{mg} / \mathrm{kg}$ than in experiment 4 (Table 1). The latter comparison is not based on any toxicokinetic data on MP after different routes of exposure, and we have no toxicokinetic data provided here to support this comparison.

\section{Hormone estimation in the testis \\ 1. Intra-testicular testosterone level}

MP increased the intra-testicular testosterone levels only in experiments 4 and 5 ( $\mathrm{p}<0.01-0.001$; Table 1). In experiment 4 , the rise of testosterone level was up to $84 \%$ and $94 \%$ above the control level, at $0.75 \mathrm{mg} /$ $\mathrm{kg}$ and $1.5 \mathrm{mg} / \mathrm{kg}$ dose-levels respectively; whereas in experiment 5 , the increase was up to $289 \%$ above the control value, indicating severe effect of p.o. exposure, although we do not have data to support the plasma concentrations of MP in relation with the observed results (Table 1).

\section{Intra-testicular LH level}

The intra-testicular LH levels were $4.52 \pm 0.51$ and $5.11 \pm 0.89$ in control groups of experiments 4 and 5 respectively, whereas the same was below the detectable limit $(<0.1 \mathrm{mIU} / \mathrm{L})$ in treated rats of both experiments.

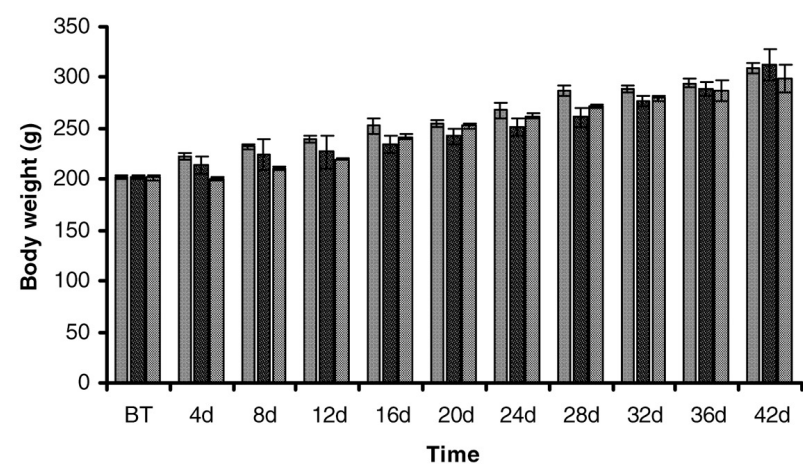

A

Fig. 1. The body weight of animals in control and MP treated rats. A) In experiment 4. Inter-group differences were significant ( $<<0.05-0.001$ ) except before treatment (BT) and on days 36 and 42 . Decrease in weight was significant at $1.5 \mathrm{mg} / \mathrm{kg} \mathrm{dose}$ groups on 4, 8, and 12 days ( $<<0.05-0.001$; every third bar in each series) and significant at $0.75 \mathrm{mg} / \mathrm{kg}$ dose-level on 16 and 24 days ( $\mathrm{p}<0.05-0.01$; every second bar in each series) and at both dose levels on 20, 28, and 32 days ( $<<0.05-0.001)$. B) In experiment 5. $\mathrm{p}<0.01$, control versus treated groups on $13^{\text {th }}$ day through $38^{\text {th }}$ day. 
Testicular toxicity of methyl parathion.

\section{Histopathological changes in the testis 1. Qualitative changes}

The testicular structure was normal in control rats with normal cell association, tubular lumen and intertubular spaces (Photo 1a). MP affected the testicular structure in all experiments, and the degree of testicular damage was more in experiment $4>5>1>3>2$. The major qualitative histopathological changes observed were shown in Photo $1 \mathrm{~b}-\mathrm{d}$. The vacuoles (Photo $1 \mathrm{~b}$ ), epithelial sloughing (Photo 1c), and gaps in the seminiferous epithelium were seen in all treated animals of all experiments. The delayed spermiation (presence of step 19 spermatids beyond stage VIII tubule) was observed in 1 rat at $3.5 \mathrm{mg} / \mathrm{kg}$ and in 3 rats at $7 \mathrm{mg} / \mathrm{kg}$ in experiment 1 ; whereas no such effect was found in treated groups of experiment 2. In experiment 3,2 rats at $0.5 \mathrm{mg} / \mathrm{kg}$ and 4 rats at $1 \mathrm{mg} / \mathrm{kg}$; in experiment 4 , all animals at $0.75 \mathrm{mg} / \mathrm{kg}$ and $1.5 \mathrm{mg} / \mathrm{kg}$; and in experiment 5 , only 3 rats at $3.5 \mathrm{mg} / \mathrm{kg}$ showed delayed spermiation. The multinucleated giant cells were observed only in experiment 4 at $0.75 \mathrm{mg} / \mathrm{kg}$ and $1.5 \mathrm{mg} / \mathrm{kg}$ dose-levels (Photo 1c and inset). The cellular changes such as nuclear pyknosis were observed in experiments 1, 4 and 5; however, the halo appearance of germ cell nuclei was observed only in experiments 4 and 5 (Photo 1c and d). The tubular atrophy was seen in all experiments, except experiment 1 , although the tubular atrophy was more in experiment $4>3>5>2$ (Photo $1 \mathrm{~b}$ and d).

\section{Quantitative changes}

The incidences of epithelial sloughing increased in experiments 2, 3 and 5 ( $\mathrm{p}<0.01-0.001$; Table 2), however, more tubules showed epithelial sloughing in experiment 3 at $1 \mathrm{mg} / \mathrm{kg}$, and in experiment 5 at 3.5 $\mathrm{mg} / \mathrm{kg}$, than in experiment 2 . In experiment 4 , the number of normal tubules significantly decreased due to increase in the number of degenerative and atrophic tubules (Fig. 2a; p<0.001). However, both of the dose- levels showed a similar effect, indicating that tubular degeneration did not relate to the strength of the dose.

\section{Morphometrical analysis of testicular damage \\ MP induced significant changes in STD and SE.} In experiment 1 , only $7 \mathrm{mg} / \mathrm{kg}$ ( $\mathrm{p}<0.05$; Fig. $2 \mathrm{~b})$; in experiment 3, at both $0.5 \mathrm{mg} / \mathrm{kg}$ and $1 \mathrm{mg} / \mathrm{kg}(\mathrm{p}<0.01)$ (Fig. 3a); and in experiment 4 (Fig. 3b), both $0.5 \mathrm{mg} / \mathrm{kg}$ and $1 \mathrm{mg} / \mathrm{kg}(\mathrm{p}<0.01-0.001)$ reduced the STD. The SE was decreased in experiment 1 at $3.5 \mathrm{mg} / \mathrm{kg}$ and $7 \mathrm{mg} /$ kg (Fig. 2b); in experiment 2, at $1 \mathrm{mg} / \mathrm{kg}$ (Fig. 3a); in experiment 3, at $0.5 \mathrm{mg} / \mathrm{kg}$ (Fig. 3b); in experiment 4, at both $0.75 \mathrm{mg} / \mathrm{kg}$ and $1.5 \mathrm{mg} / \mathrm{kg}$ (Fig. 3c); and in experiment 5, at $3.5 \mathrm{mg} / \mathrm{kg}$ (Fig.3d; p<0.05-0.001). Taken together, the i.p. exposure to $0.75 \mathrm{mg} / \mathrm{kg}$ and 1.5 $\mathrm{mg} / \mathrm{kg}$ for 25 days in experiment 4 was more effective to reduce the STD and SE than the dose-levels used in other experiments or p.o. exposure in experiment 5 . The reason for this difference is not known. Due to nuclear degenerative changes, the volume of germ cell nuclei significantly decreased in experiment 4 (Table 3 ). The decrease in nuclear volume of spermatogonia and round spermatids took place in a dose-dependent pattern, but not of primary spermatocytes.

\section{Cytotoxicity of MP in the testis}

MP decreased the number of homogenizationresistant spermatids in experiments 1,4 and 5 in a dose-dependent manner (Table 4). The p.o. exposure to $3.5 \mathrm{mg} / \mathrm{kg}$ in experiment 5 was more effective to reduce the spermatid count than i.p. treatments either in experiment 1 or 4 . The incidences of stage XIV tubules decreased in treated groups of experiments 2 , 3 , and 5 ( $\mathrm{p}<0.01-0.001$; Table 5). The effect was more in experiments 2 and 5 than in experiment 3 . The meiotic figures in the seminiferous epithelium were also decreased in experiments 2, 3 and 5 ( $\mathrm{p}<0.01-0.001$; Table 5). In experiment 2 , a significant decrease in meiotic figures was observed only at $1 \mathrm{mg} / \mathrm{kg}$ dose-

Table 1. Testis weight and intra-testicular testosterone level in control and MP treated rats.

\begin{tabular}{cccc}
\hline Experiment & Doses/ mg/kg & Testis weight $(\mathrm{g})$ & Testosterone level (ng/g testis) \\
\hline 4 & 0 (i.p.) & $1.76 \pm 0.05$ & $98.13 \pm 3.12$ \\
& 0.75 (i.p.) & $1.44 \pm 0.20^{* *}$ & $180.41 \pm 11.21^{* * *}$ \\
& 1.5 (i.p.) & $1.48 \pm 0.13^{* *}$ & $190.32 \pm 10.61^{* * *}$ \\
\hline 5 & 0 (p.o.) & $1.76 \pm 0.05$ & $95.32 \pm 7.11$ \\
& 3.5 (p.o.) & $1.18 \pm 0.03^{* *}$ & $370.48 \pm 15.12^{* *}$ \\
\hline
\end{tabular}

Inter-group differences for testis weight and testosterone level were significant in experiment $4(\mathrm{p}<0.01)$.

$* \mathrm{p}<0.01$, control versus treated groups. 
level. Both i.p. and p.o. exposures were equally effective to decrease the meiotic figures, and hence the cell proliferation. Elongating spermatids also significantly decreased in experiments 2, 3 and 5. The effect was more in experiments 3 and 5 than in experiment 2 $(\mathrm{p}<0.01-0.001 ;$ Table 5).

\section{DISCUSSION}

Previous studies have revealed the fact that MP
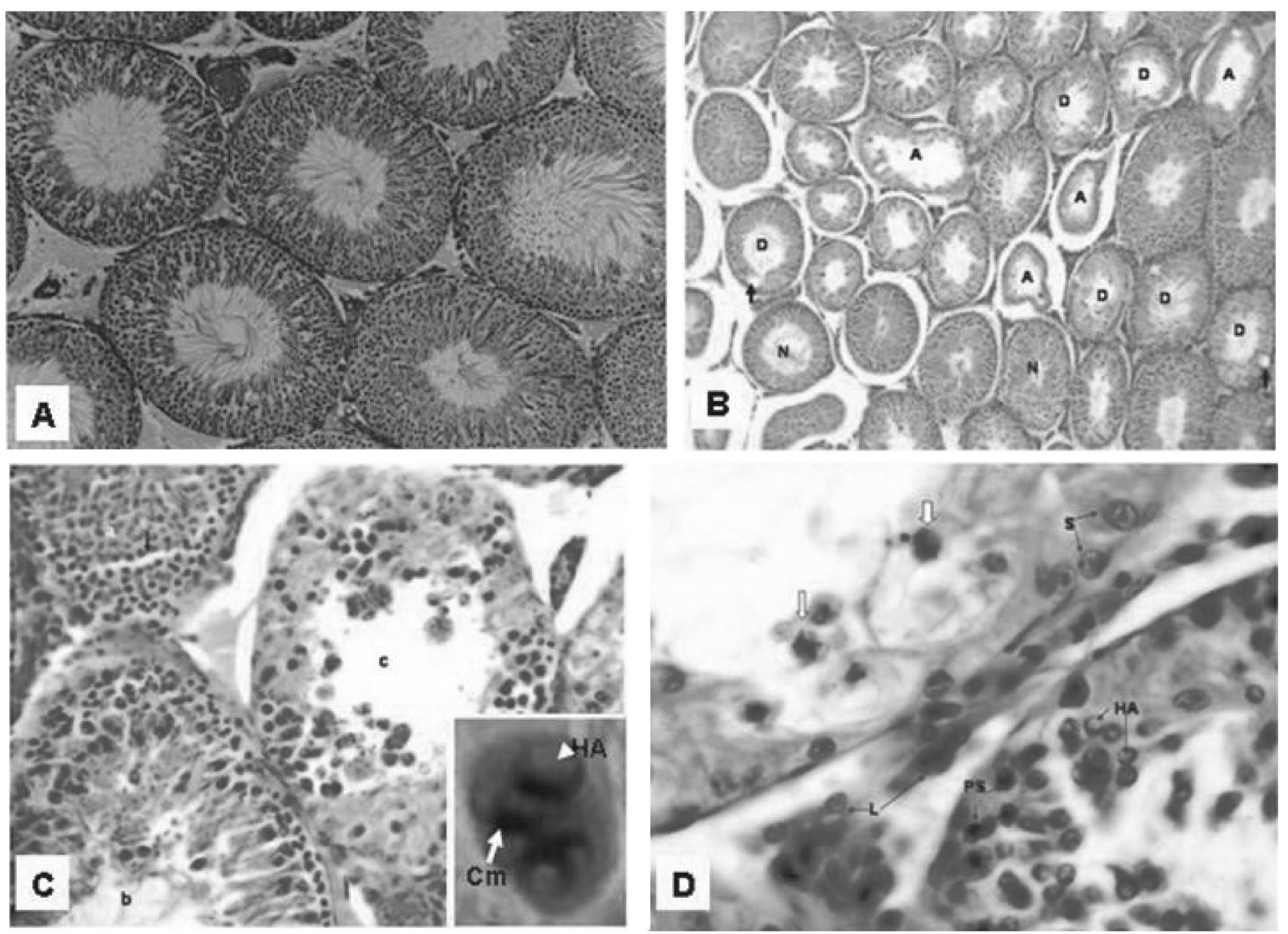

Photo 1. Photomicrographs of testicular sections of control and MP treated rats. A) Photomicrograph of a control testis from experiment 4 showing normal spermatogenesis. Note the normal cell arrangement in the seminiferous tubules. The inter-tubular spaces and Leydig's cells also appear normal, PAS-H\&E, 90×. B) Photomicrograph of a testicular section of a rat treated with $0.75 \mathrm{mg} / \mathrm{kg}$ on $17^{\text {th }}$ day (experiment 4). The normal $(\mathrm{N})$ and abnormal tubules were labeled. Many tubules show degeneration (D); note that the epithelium in each of such tubules shows disintegration and some of them also show vacuoles (arrows). Atrophic tubules (A) show very few germ cells; note that the inter-tubular spaces are enlarged due to tubular atrophy. Atrophic or degenerative tubules also show multinucleated cells. PAS-H\&E, 90×. C) A testicular section from a rat treated with $1.5 \mathrm{mg} / \mathrm{kg}$ on $17^{\text {th }}$ day (experiment 4). Three tubules are shown with different degrees of degeneration. In tubule a, epithelial sloughing is apparent (arrow); in tubule b, the cells are desquamated and nuclei are pyknotic and germ cells are in the process of formation of multinucleated cells. In tubule $\mathrm{c}$, the degeneration is further advanced, and large multinucleated cells are seen. Besides, PAS or eosin positive bodies are seen everywhere in the epithelium. PAS-H\&E, 360×. Inset- a multinucleated giant cell showing the halo appearance (HA) and chromatin margination $(\mathrm{Cm})$ in round spermatid nuclei. PAS-H\&E, 1170×. D) A testicular section of a rat treated with $1.5 \mathrm{mg} / \mathrm{kg}$ on $17^{\text {th }}$ day (experiment 4) showing atrophy of tubules. The upper tubule is more or less in "Sertoli cell only" condition showing a very few degenerating germ cells (open arrows) but relatively normal Sertoli cell nuclei (S). The lower tubule shows some round spermatids with 'halo' appearance (HA), and spermatocytes present darkly stained pyknotic nuclei (PS). PAS-H\&E, 360×. 
Testicular toxicity of methyl parathion.

was capable of inducing structural and functional changes (Asmathbanu and Kaliwal, 1997; Dhondup and Kaliwal, 1997), and biochemical alterations in the ovary (Kaur and Dhanju, 2005), as well as in the placenta (Levario-Carrillo et al., 2004). The present study investigated the toxic effects of MP on the testis, and results indicated that MP affected the testicular structure and function.

\section{Body weight and testis weight}

Prolonged i.p. or p.o. exposures to MP, rather than exposures for 5 days or 12 days, decreased the body weight (Fig. 1 a and b) in consensus with the earlier reports (IPCS, 1993; Solecki et al., 1996), and that effect was due to diminished food and water intake in treated rats of experiments 4 and 5 (Solecki et al., 1996). Decrease in testis weight only in rats belonging to experiments 4 and 5 revealed the fact that sufficient gonadotoxicity could be seen only after prolonged exposure to MP, regardless of routes of exposure (Table 1). Other authors have also observed similar effects after treating very low doses of MP, although to a very

Table 2. Effect of MP on epithelial sloughing in the testis.

\begin{tabular}{ccc}
\hline Experiment & Groups & \%tubules with sloughing \\
\hline 2 & Control & $0.40 \pm 0.55$ \\
& $0.5 \mathrm{mg} / \mathrm{kg}$ & $6.00 \pm 1.87^{* * *}$ \\
& $1 \mathrm{mg} / \mathrm{kg}$ & $4.80 \pm 1.92^{* * *}$ \\
\hline 3 & Control & $0.40 \pm 0.55$ \\
& $0.5 \mathrm{mg} / \mathrm{kg}$ & $3.80 \pm 0.84^{* * *}$ \\
& $1 \mathrm{mg} / \mathrm{kg}$ & $11.80 \pm 1.48^{* * *}$ \\
\hline 5 & Control & $0.40 \pm 0.55$ \\
& $3.5 \mathrm{mg} / \mathrm{kg}$ & $11.80 \pm 3.03^{* *}$ \\
\hline
\end{tabular}

$\mathrm{p}<0.001$-inter-group differences in experiments 2 and $3 ; * * \mathrm{p}<0.01, * * * \mathrm{p}<0.001$ control versus treated groups.
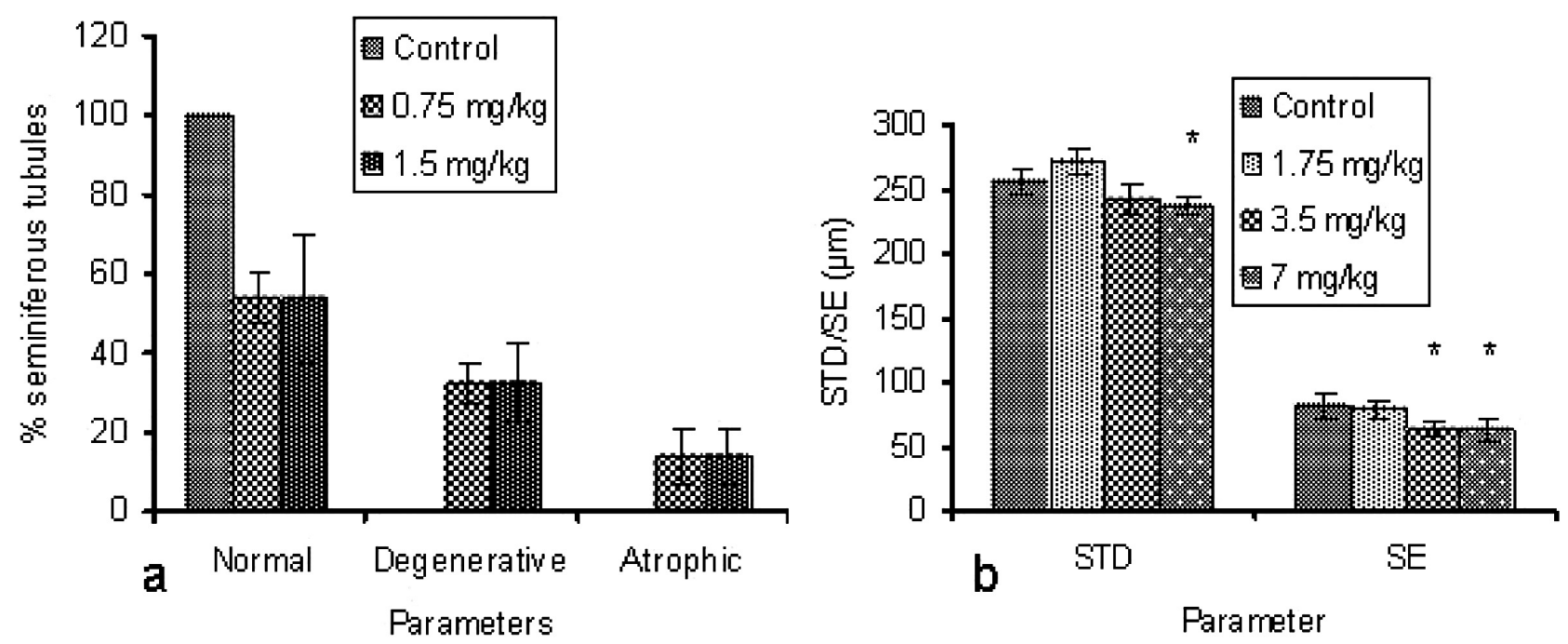

Fig. 2. a) Classification of seminiferous tubules in the testes of control and MP treated rats of experiment 4 . The seminiferous tubules were classified into normal, degenerative and atrophic based on the degree of seminiferous epithelium disruption. Normal tubules showed normal cell association, the degenerative tubules showed cellular degeneration and epithelial exfoliation and the atrophic tubules showed very few or no germ cells. The comparison is between each type of tubule in control or treated groups. Note that no degenerative or atrophic tubule in control group. Inter-group differences are significant $(\mathrm{p}<0.001)$. $\mathrm{p}<0.001$, control versus treated groups. b) The diagram showing the STD and SE in experiment 1 . The STD was decreased at 7 $\mathrm{mg} / \mathrm{kg}$ dose-level, whereas the SE was decreased at $3.5 \mathrm{mg} / \mathrm{kg}$ and $7 \mathrm{mg} / \mathrm{kg}$ dose-level on $14^{\text {th }}$ day. $\mathrm{p}<0.001$-inter-group differences for STD and SE. p $<0.05$, control versus treated groups. 
rare experimental model-white-throated munias (Lonchura malabarica)- possibly due to decreased acetylcholinesterase level in the testis (Maitra and Sarkar, 1996). Although we have not estimated the acetylcholinestrase activity in the testis, the previous studies have shown that MP inhibited the activities of this enzyme (IPCS, 1993), and decreased acetylcholinesterase activity was observed along with severe testicular damage in quinalphos-treated rats (Sarkar et al., 2000). Thus, we presume that the testicular damage induced in the present case might have a relation with decreased acetylcholinesterase activity, although this assumption has to be investigated further. Decrease in the testis weight in the present case was due to germ cell loss and testicular atrophy, as seen in other experimental conditions (Hess et al., 1988; Nakai et al., 1992; Narayana et al., 2000).

\section{Hormone estimation in the testis}

A spectacular rise in testosterone level in experiment 5 compared to experiment 4 (Table 1), indicates that p.o. treatment may be more effective to induce the hormonal disturbances than the i.p. exposure, although we do not have any toxicokinetic data such as plasma

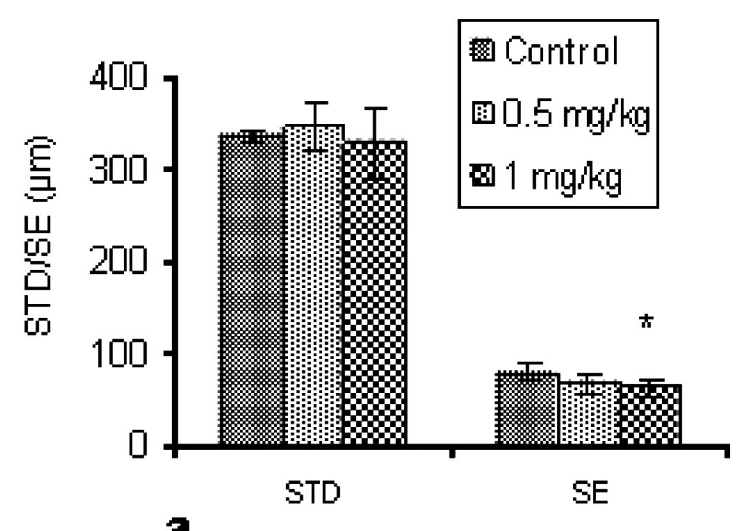

Far arreter
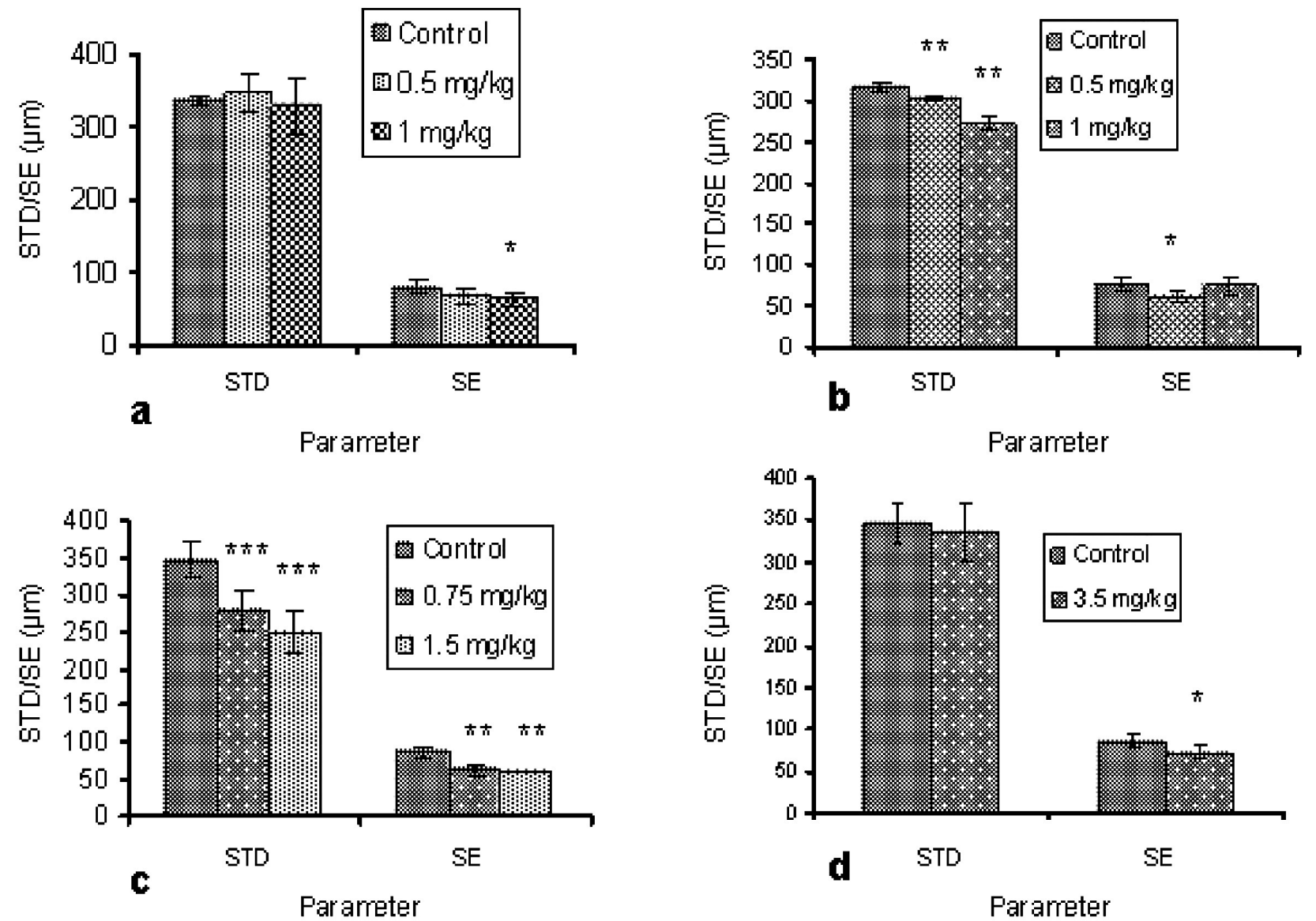

Par arreter

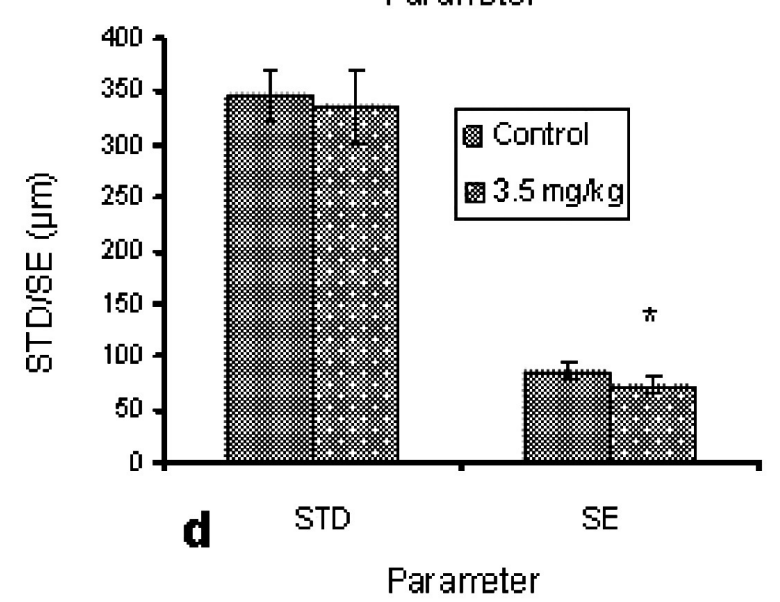

Fig. 3. The STD and SE in the testes of control and MP treated rats in experiments 2-5. a) In experiment 2, the STD did not show any significant differences with control whereas the SE was decreased at $1 \mathrm{mg} / \mathrm{kg}$ dose level $\left({ }^{*} \mathrm{p}<0.05\right)$ with inter-group differences $(\mathrm{p}<0.05)$. b) In experiment 3, the STD was decreased at $0.5 \mathrm{mg} / \mathrm{kg}$ and $1 \mathrm{mg} / \mathrm{kg}$ dose-levels $(* * \mathrm{p}<0.01)$ against control with inter-group differences $(\mathrm{p}<0.01)$, whereas the SE was decreased only at $0.5 \mathrm{mg} / \mathrm{kg}$ dose-level $\left({ }^{*} \mathrm{p}<0.05\right)$, but with inter-group differences $(\mathrm{p}<0.05)$. c) In experiment 4 , both STD $(* * * \mathrm{p}<0.001)$ and SE $(* * \mathrm{p}<0.01)$ was decreased against control with intergroup differences $(\mathrm{p}<0.001)$. In experiment 4 , the tubular shrinkage as well as epithelial thinning was evident compared to other experiments due to tubular atrophy. d) In experiment 5, the STD did not show any significant change, but the SE decreased at $3.5 \mathrm{mg} / \mathrm{kg}$ dose-level against control $(* \mathrm{p}<0.05)$. 
Testicular toxicity of methyl parathion.

levels of MP or its metabolites after different routes of exposure. Therefore, this assumption is purely based on different concentrations of hormone in experiments 4 and 5. Even the comparison of effects of MP after i.p. or p.o. routes of exposure on other parameters employed in this study is also not based on any toxicokinetic data, rather based only on actual differences in different parameters. MP induced the accumulation of testosterone, possibly by interfering with the latter's binding to androgen receptors or metabolism. This may be the reason for decrease in weights of androgendependent organs-prostate and seminal vesicle (Narayana et al., unpublished data). This action of MP partly is in consensus with that of flutamide or vinclozolin, in which testosterone level increased due to sup- pression of feed-back inhibition of androgens on the anterior pituitary (O'Connor et al., 1998). The suppression of feedback inhibition may secondarily increase the LH secretion and a blockade of Leydig cell androgen receptors, leading to increased secretion of testosterone (Andrews et al., 2001; Yu et al., 2004). However, in the present study, the LH level was also decreased in the treated testis, indicating a direct effect on the anterior pituitary. Thus, a further study is required to confirm the effects of MP on the pituitary or hypothalamus.

\section{Histopathological changes in the testis \\ 1. Qualitative changes}

The qualitative changes in the testis were appar-

Table 3. Effect of methyl parathion on volume $\left(\mu \mathrm{m}^{3}\right)$ of nuclei of germ cells in experiment 4 .

\begin{tabular}{clcc}
\hline Groups & Spermatogonia & Primary spermatocytes & Round spermatids \\
\hline Control (i.p.) & $99.22 \pm 25.51$ & $407.88 \pm 55.22$ & $185.63 \pm 16.07$ \\
$0.75 \mathrm{mg} / \mathrm{kg}$ (i.p.) & $46.25 \pm 0.48^{*}$ & $222.42 \pm 43.71^{*}$ & $138.75 \pm 6.80^{*}$ \\
$1.5 \mathrm{mg} / \mathrm{kg}$ (i.p.) & $35.00 \pm 8.19^{*}$ & $237.40 \pm 33.71^{*}$ & $117.17 \pm 18.26^{*}$ \\
\hline
\end{tabular}

$\mathrm{p}<0.001$, inter-group differences, and $* \mathrm{p}<0.001$, control versus treated groups.

Table 4. Homogenization resistant spermatid count in control and MP treated rats.

\begin{tabular}{ccc}
\hline Experiment & Doses $/ \mathrm{mg} / \mathrm{kg}$ & Spermatid count $\left(\times 10^{6}\right)$ \\
\hline 1 & 0 (i.p.) & $41.21 \pm 2.11$ \\
& 1.75 (i.p.) & $29.11 \pm 1.31^{* * *}$ \\
& 3.5 (i.p.) & $26.19 \pm 1.38^{* * * *}$ \\
\hline 4 & 7 (i.p.) & $25.21 \pm 2.18^{* * *}$ \\
\hline 5 & 0 (i.p.) & $40.32 \pm 2.17$ \\
& 0.75 (i.p.) & $31.33 \pm 1.96^{* * *}$ \\
& 1.5 (i.p.) & $23.19 \pm 1.37^{* * *}$ \\
\hline
\end{tabular}

Inter-group differences were significant in experiments 1 and $4(\mathrm{p}<0.001) ; * \mathrm{p}<0.01, * * * \mathrm{p}<0.001$, control versus treated groups.

Table 5. Effect of MP on cytotoxic parameters in stage XIV seminiferous tubules in the testis.

\begin{tabular}{cllll}
\hline Experiment & Groups & \% stage XIV tubules & \multicolumn{1}{c}{ MF/SN } & ES:SN \\
\hline 2 & Control & $8.00 \pm 1.00$ & $3.06 \pm 0.80$ & $9.56 \pm 0.76$ \\
& $0.5 \mathrm{mg} / \mathrm{kg}$ & $2.40 \pm 0.89^{* * *}$ & $2.66 \pm 0.56$ & $6.77 \pm 0.50^{* * *}$ \\
& $1 \mathrm{mg} / \mathrm{kg}$ & $2.80 \pm 1.30^{* * *}$ & $1.38 \pm 0.37^{* *}$ & $6.37 \pm 0.46^{* * *}$ \\
\hline 3 & Control & $7.20 \pm 1.30$ & $2.99 \pm 0.38$ & $8.90 \pm 0.87$ \\
& $0.5 \mathrm{mg} / \mathrm{kg}$ & $4.20 \pm 0.84^{* *}$ & $1.48 \pm 0.37^{* *}$ & $5.90 \pm 0.47^{* *}$ \\
& $1 \mathrm{mg} / \mathrm{kg}$ & $4.40 \pm 0.89^{* *}$ & $1.50 \pm 0.35^{* *}$ & $4.34 \pm 0.59^{* *}$ \\
\hline 5 & Control & $8.00 \pm 1.00$ & $3.06 \pm 0.80$ & $9.56 \pm 0.76$ \\
& $3.5 \mathrm{mg} / \mathrm{kg}$ & $3.20 \pm 0.84^{* *}$ & $1.26 \pm 0.23^{* *}$ & $4.57 \pm 0.70^{* *}$ \\
\hline
\end{tabular}

$\mathrm{MF} / \mathrm{SN}=$ meiotic figures/ Sertoli cell nucleolus, and ES:SN= Elongated spermatids/ Sertoli cell nucleolus in stage XIV tubules. $\mathrm{p}<0.001$, inter-group differences in experiments 2 and $3 ; * * \mathrm{p}<0.01, * * * \mathrm{p}<0.001$ control versus treated groups. 
ent in all experiments, but more severe damage was observed in experiment 4 after i.p. exposure to 0.75 $\mathrm{mg} / \mathrm{kg}$ or $1.5 \mathrm{mg} / \mathrm{kg}$ for 25 days. The major defects were epithelial sloughing, multinucleated giant cells, necrosis of seminiferous epithelium, cellular degeneration and finally the tubular atrophy. Sloughing of epithelium is an aftermath of Sertoli cell damage owing to microtubule disruption (Nakai et al., 1995), and this phenomenon naturally leads to tubular atrophy (Hess and Nakai, 2000). Moreover, formation of multinucleated cells, epithelial sloughing, and cell death in the testis are inter-related and cordially orchestrated during initiation of tubular atrophy (Hess and Nakai, 2000). Cellular degeneration was evident in terms of halo appearance (Photo 1c inset), nuclear pyknosis, multinucleated cell formation, and fragmentation of nuclei in pre-atrophic tubules (degenerating tubules), a mechanism akin to the one seen with other chemicals such as 5-fluorouracil or tamoxifen citrate (D'Souza and Narayana, 2002; D'Souza, 2003). The halo appearance of round spermatid nuclei and the formation of giant cells are common deformities caused by several chemicals (for review Hess et al., 1988). The giant multinucleated cells observed in the present study or in other studies (Chapin et al., 1983; Hess et $a l ., 1988)$ may be the end result of germ cell degeneration and widening of intercellular bridges (Hess et al., 1988). Abnormal seminiferous epithelium and decreased acetylcholinesterase level was observed in white-throated munias, along with normal Leydig cell architecture (Maitra and Sarkar, 1996). In the present study also, Leydig cells maintained normal structure, although testosterone level increased. In general, antiandrogens induce structural changes in the testis, characterized by hypertrophy of Leydig cells (Andrews et al., 2001; Yu et al., 2004). In the present study, changes in the testicular structure were observed, although Leydig cells were normal, thus making a difference with a typical anti-androgen. The qualitative changes induced were similar to the effects of other drugs such as 5-fluorouracil (Narayana et al., 2000; D'Souza and Narayana, 2001), or chemicals such as carbendazim (Hess et al., 1988, 1991; Nakai et al., 1995).

\section{Quantitative changes}

Epithelial sloughing was limited in the present case, but the tubular degeneration resulting in cell loss from the epithelium in experiments 4 and 5 led to increased luminal area (Photo 1c and d). Quantitatively, the incidences of epithelial sloughing decreased by the $130^{\text {th }}$ day in experiment 2 compared to the $77^{\text {th }}$ day in experiment 3 may be due to the recovery effect. In experiment 5 , however, the tubules with epithelial sloughing remained higher by the $17^{\text {th }}$ day. In any case, the incidences of tubules with sloughing did not exceed the $12 \%$ mark. In experiment 4 , we did not estimate the tubules with sloughing, as well as other cytotoxic parameters in stage XIV tubules, due to extensive tubular damage. Degenerative (pre-atrophic) and completely degenerated (atrophic) tubules increased in this experiment, but very few tubules were atrophic in experiment $5(3 \%)$, revealing that i.p. treatment was more effective to induce this damage. The tubular atrophy began as epithelial sloughing and necrosis of the seminiferous epithelium.

\section{Morphometrical analysis of testicular damage}

Due to the degenerative changes, the seminiferous tubules and the epithelium showed shrinkage (Hess and Nakai, 2000) leading to decrease in STD and SE, especially in experiment 4 . The tubular atrophy was more in the testes of treated rats of experiment 4 , which resulted in very highly significant reduction in STD and SE (Fig. 3c). The significant decrease in volumes of different types of germ cells (Table 3 ) indicates the cellular degeneration, which resulted in thinning of seminiferous epithelium.

\section{Cytotoxicity of MP in the testis}

MP also decreased the spermatid count in experiments 1, 4 and 5, indicating its cytotoxic effect on germ cells (Sprando et al., 2005), and the p.o. exposure in experiment 5 was more effective (Table 4). The decrease in spermatid number owing to cytotoxic effects of MP was the underlying reason for reduced sperm count reported in earlier studies, although there was no effect on sperm count at the dose-levels of 1.75 to $7 \mathrm{mg} / \mathrm{kg}$ on day 14, post treatment (Narayana et al., 2005a). The latter effect may be due to a shorter sample period by which time the testicular effect was not reflected in epididymal sperm concentration. MP was cytotoxic when evaluated in the rat in terms of decreased spermatogenesis with positive correlation with decreased ascorbic acid level in the testis (Narayana et al., 2005a), although there was no such effect in mice (Mathew et al., 1992). In the present study, besides decreasing spermatid count in the testis, MP also decreased incidences of stage XIV tubules, as well as meiotic figures and step 14 spermatids, indicating its inhibitory effect on cell division and advancement of previous stages into stage 14 .

In conclusion, the present results indicate that 
Testicular toxicity of methyl parathion.

MP is a reproductive toxicant in males. Exposure to MP results in disturbances in testosterone and $\mathrm{LH}$ in the testis. The results also confirm that MP induces tubular atrophy by causing cell death and the formation of multinucleated cells in the testis.

\section{REFERENCES}

Aleem, A. and Malik, A. (2005): Genotoxicity of the Yamuna River water at Okhla (Delhi), India. Ecotoxicol. Environ. Saf., 61, 404-412.

Andrews, P., Freyberger, A., Hartmann, E., Eiben, R., Loof, I., Schmidt, U., Temerowski, M. and Becka, M. (2001): Feasibility and potential gains of enhancing the sub acute rat study protocol (OECD test guideline no. 407) by additional parameters selected to determine endocrine modulation. A prevalidation study to determine endocrine-mediated effects of the antiandrogenic drug flutamide. Arch. Toxicol., 75, 65-73.

Asmathbanu, I. and Kaliwal, B.B. (1997): Temporal effect of methyl parathion on ovarian compensatory hypertrophy, follicular dynamics and estrous cycle in hemicastrated albino rats. J. Basic. Clin. Physiol. Pharmacol., 8, 237-254.

Barr, D., Allen, B.R., Olsson, A.O., Bravo, R., Caltabiano, L.M., Montesano, A., Nguyen, J., Udunka, S., Walden, D., Walker, R.D., Weerasekera, G., Whitehead, R. D. Jr., Schober, S.E. and Needham, L.L. (2005): Concentrations of selective metabolites of organophosphorus pesticides in the United States population. Environ. Res., 99, 314-326.

Chapin, R.E., Ross, M.D. and Lamb, J.C. (1983): The morphogenesis of testicular degeneration induced in rats by orally administered 2, 5-hexanedione. Exp. Mol. Pathol., 38, 149-169.

Culling, C.F.A., Allison, R.T. and Barr, W.T. (1985): Cellular pathology technique, 4th Edition. pp. 27-50, Butterworths, London.

D'Souza, U.J.A. (2003): Tamoxifen induced multinucleated cells (symplasts) and distortion of seminiferous tubules in rat testis. Asian. J. Androl., 5, 217-220.

D'Souza, U.J.A. and Narayana, K. (2001). Induction of seminiferous tubular atrophy by single dose of 5-fluorouracil (5-FU) in Wistar rats. Indian. J. Physiol. Pharmacol., 45, 87-94.

D'Souza, U.J.A. and Narayana, K. (2002): Mechanism of cytotoxicity of ribavirin in the rat bone marrow and testis. Indian. J. Physiol. Pharmacol.,
46, 468-474.

Dhondup, P. and Kaliwal, B.B. (1997). Inhibition of ovarian compensatory hypertrophy by the administration of methyl parathion in hemicastrated albino rats. Reprod. Toxicol., 11, 77-84.

Gupta, R.C., Rech, R.H., Lovell, K.L., Welch, F. and Thornburg, J.E. (1985): Brain cholinergic, behavioral, and morphological development in rats exposed in utero to methyl parathion. Toxicol. Appl. Pharmacol., 77, 405-413.

Gupta, R.C., Thornburg, J.F., Stedman, D.B. and Welsch, F. (1984): Effect of subchronic administration of methyl parathion on in vivo protein synthesis in pregnant rats and their conceptuses. Toxicol. Appl. Pharmacol., 92, 457-468.

Hess, R.A., Linder, R.E., Strader, L.F. and Perreault, S.D. (1988): Acute effects and long-term sequelae of 1,3-dinitrobenzene on male reproduction in the rat II. Quantitative and qualitative histopathology of the testis. J. Androl., 9, 327342.

Hess, R.A., Moore, B.J., Forrer, J., Linder, R.E. and Abuel-Atta, A.A. (1991): The fungicide benomyl (Methyl 1 (1-(Butylcarbamoyl)-2benzimidazole carbamate) causes testicular dysfunction by inducing the sloughing of germ cells and occlusion of efferent ductules. Fundament. Appl. Toxicol., 17, 733-745.

Hess, R.A. and Nakai, M. (2000): Histopathology of the male reproductive system induced by the fungicide benomyl. Histol. Histopathol., 15, 207-224.

IPCS (International Programmme on Chemical Safety). (1993): Environmental Health Criteria 145, Methyl Parathion, WHO, pp. 11-236.

Jelinek, R., Peterka, M. and Rychter, Z. (1985): Chick embryo toxicity screening test-130 substances tested. Indian. J. Exp. Biol., 23, 588-595.

Kaur, S. and Dhanju, C.K. (2005): Biochemical effects of some organophosphorus pesticides on the ovaries of albino rats. Indian. J. Physiol. Pharmacol., 49, 148-152.

Kumar, K.B. and Devi, K.S. (1992): Teratogenic effects of methyl parathion in developing chick embryos. Vet. Hum. Toxicol., 34, 408-410.

Levario-Carrillo, M., Olave, M.E., Corral, D.C., Alderete, J.G., Gagioti, S.M. and Bevilacqua, E. (2004): Placental morphology of rats prenatally exposed to methyl parathion. Exp. Toxicol. Pathol., 55, 489-496.

Ma, T., Kramer, R.E., Baker, R.C., Fan, L.W. and Ho, 
I.K. (2003): Effects of chronic dermal exposure to nonlethal doses of methyl parathion on brain regional acetylcholinesterase and muscarinic cholinergic receptors in female rats. J. Neurosci. Res., 71, 138-145.

Maitra, S.K. and Sarkar, R. (1996): Influence of methyl parathion on gametogenic and acetylcholinesterase activity in the testis of whitethroated munia (Lonchura malabarica). Arch. Environ. Contam. Toxicol., 30, 384-389.

Makita, Y., Omura, M., Tanaka, A. and Kiyohara, C. (2005): Effects of concurrent exposure to tributyltin and 1, 1-dichloro-2, 2 bis ( $p$-chlorophenyl) ethylene ( $p, p$ '-DDE) on immature male Wistar rats. Basic. Clin. Pharmacol. Toxicol., 97, 364-368.

Mathew, G., Vijayalaxmi, K.K. and Rahiman, M.A. (1992): Methyl parathion induced sperm shape abnormalities in mouse. Mutation. Res., 280, 169-173.

Nakai, M., Hess, R.A., Moore, B.J., Guttroff, R.F., Strader, L.F. and Linder, R.E. (1992): Acute and long-term effects of a single dose of the fungicide carbendazim (methyl 2-benzimidazole carbamate) on the male reproductive system in the rat. J. Androl., 13, 507-518.

Nakai, M., Hess, R.A., Netsu, J. and Nasu, T. (1995): Deformation of the rat Sertoli cell by oral administration of carbendazim (methyl 2-benzimidazole carbamate). J. Androl., 16, 410-416.

Narayana, K., Prashanthi, N., Nayanatara, A., Kumar, H.H.C., Abhilash, K. and Bairy, K.L. (2005a): Effects of methyl parathion (o, $o$-dimethyl $o$-4nitrophenyl phosphorothioate) on rat sperm morphology and sperm count, but not fertility, are associated with decreased ascorbic acid level in the testis. Mutation. Res., 588, 28-34.

Narayana, K., D’Souza, U.J.A., Prashanthi, N. and Ganesh, K. (2005b): The antiviral drug ribavirin reversibly affects the reproductive parameters in the male Wistar rat. Folia. Morphol., 64, 65-71.

Narayana, K., D'Souza, U.J.A. and Rao, K.P.S. (2002): Effect of ribavirin on epididymal sperm count in rat. Indian. J. Physiol. Pharmacol., 46, 97-101.

Narayana, K., D’Souza, U.J.A., Sanyal, A.K. and Rao, K.P.S. (2000): 5-Fluorouracil (5-FU) induces the formation of giant cells and sloughing of seminiferous epithelium in the rat testis. Indian. J. Physiol. Pharmacol., 44, 317-322.

O’Connor, J.C., Cook, J.C., Slone, T.W., Makovec,
G.T., Frame, S.R. and Davis, L.G. (1998): An ongoing validation of a Teir I screening battery for detecting endocrine-active compounds (EACs). Toxicol. Sci., 46, 45-60.

Rubin, C., Esteban, E., Hill, R.H. Jr. and Pearce, K. (2002): Introduction- the methyl parathion story: A chronicle of misuse and preventable human exposure. Environ. Health. Perspect., 110 (Suppl 6), 1037-1040.

Ruckart, P.Z., Kakolewski, K., Bove, F.J. and Kaye, W.E. (2004): Long-term neurobehavioral health effects of methyl parathion exposure in children in Mississippi and Ohio. Environ. Health. Perspect., 112, 46-51.

Sarkar, R., Mohanakumar, K.P. and Chowdhury, M. (2000): Effects of an organophosphate pesticide, quinalphos, on the hypothalamo-pituitarygonadal axis in adult male rats. J. Reprod. Fertil., 118, 29-38.

Sharpe, R.M. and Irvine, D.S. (2004): How strong is the evidence of a link between environmental chemicals and adverse effects on human reproductive health? Brit. Med. J., 328, 447-451.

Sharpe, R. M. and Skakkebaek, N. E. (1993): Are estrogens involved in falling sperm counts and disorders of the male reproductive tract? Lancet., 341, 1392-1395.

Solecki, R., Faqi, A.S., Pfeil, R. and Hilbig, V. (1996): Effects of methyl parathion on reproduction in the Japanese quail. Bull. Environ. Contam. Toxicol., 57, 902-908.

Sprando, R.L., Collins, T.F., Black, T.N., Olejnik, N., Rorie, J.I., Eppley, R.M. and Ruggles, D.I. (2005): Characterization of the effect of deoxynivalenol on selected male reproductive endpoints. Food. Chem. Toxicol., 43, 623-635.

Tang, J., Carr, R.L. and Chambers, J.E. (2003): The effects of repeated oral exposures to methyl parathion on rat brain cholinesterase and muscarinic receptors during postnatal development. Toxicol. Sci., 76, 400-406.

Toppari, J., Larsen, J.C., Christiansen, P., Giwercman, A., Grandjean, P., Guillette, L.J.Jr. (1996): Male reproductive health and environmental xenoestrogens. Environ. Health. Perspect., 104 (Suppl 4), 741-803.

Vega, S.G., Guzman, P., Garcia, L., Espinosa, J. and De Nava, C.C. (1988): Sperm shape abnormality and urine mutagenicity in mice treated with niclosamide. Mutation. Res., 204, 269-276.

Vernagy, L. and Deli, E. (1985): Comparative terato- 
Testicular toxicity of methyl parathion.

logical study of insecticide Wolfatox 50EC (50\% methyl parathion) on chicken and pheasant fetuses. Anat. Anz. Jena., 158, 1-3.

Wesseling, C., Antich, D., Hogstedt, C., Rodriguez, A. C. and Ahlbom, A. (1999): Geographical differences of cancer incidence in Costa Rica in relation to environmental and occupational pesticide exposure. Int. J. Epidemiol. 28, 365-374.

Yu, W.J., Lee, B.J., Nam, S.Y., Ahn, B., Hong, J.T., Do, J.C., Kim, Y.C., Lee, Y.S. and Yun, Y.W.
(2004): Reproductive disorders in pubertal and adult phase of the male rats exposed to vinclozolin during puberty. J. Vet. Med. Sci., 66, 847853.

Zeitz, P., Kakolewski, K., Imtiaz, R. and Kaye, W. (2002): Methods of assessing neurobehavioral development in children exposed to methyl parathion in Mississippi and Ohio. Environ. Health. Perspect., 110 (Suppl 6), 1079-1083. 